DOI 10.18551/rjoas.2021-04.06

\title{
EFFECT OF ADVERTISING AND SERVICE QUALITY ON CUSTOMER'S DECISION STAY AT THE ROYAL HOTEL DARMO MALIOBORO YOGYAKARTA
}

\author{
Astrika Octama Deo* \\ Master's Study Program of Management, University of Sriwijaya, Palembang, Indonesia \\ Wahab Zakaria, Widiyanti Marlina \\ Department of Management, Faculty of Economics, University of Sriwijaya, Palembang, \\ Indonesia \\ *E-mail: octamadeomm@gmail.com
}

\begin{abstract}
This research was conducted to determine the effect of hotel advertising and service quality on consumer decisions at Royal Darmo Malioboro Yogyakarta. The population in this study is all consumers who stay at Hotel Royal Darmo Malioboro Yogyakarta at least more than one night. The samples used in this study were 100 respondents using a sampling technique using a non-probability sampling method. The data collection method used questionnaires and data processing techniques used multiple linear regression analysis. The results of the analysis show that advertising has a positive and significant effect on consumer decisions to stay at Hotel Royal Darmo Malioboro Yogyakarta. Service quality has a positive and significant effect on consumer decisions to stay at Hotel Royal Darmo Malioboro Yogyakarta. Advertising is expected to increase advertising on electronic media in conducting promotions. The quality of service requires routine maintenance of the building and other hotel facilities.
\end{abstract}

\section{KEY WORDS}

Advertising, service quality, consumer, decisions.

Hotel is a form of business that is engaged in services to hotel guests both physically, psychologically and safely as long as guests use the facilities or enjoy services at the hotel (Agusnawar, 2000). The hotel business is currently growing rapidly, where each hotel has to compete fiercely in order to continue to grow and develop. Companies in the hotel industry are required to recognize consumer behavior and then adjust the company's ability to meet consumer needs and desires. As rapidly changing needs and desires have an impact that makes the choice of services even more complicated, including in the hotel industry. This consumer behavior will have an impact and influence on the consumer's decision process to choose an item or service that he will choose (Setiawati, 2016). The consumer's decision to make a purchase is a person's attitude to buy or use a product in the form of goods or services that are believed to satisfy him and his willingness to bear the risks that may result (Kotler \& Keller, 2016).

Table 1 - The number of starred hotels and Accommodation in Yogyakarta, 2017-2019

\begin{tabular}{lllll}
\hline Year / Classification & 2017 & 2018 & $2019 \%$ & Improvement In (2017-2019) \\
\hline starred hotels & 82 & 90 & 163 & $49.69 \%$ \\
Other property & 356 & 490 & 1,636 & $78.24 \%$ \\
Total & 438 & 580 & 1,799 & $75.65 \%$ \\
\hline
\end{tabular}

Source: Yogyakarta Province Central Bureau of Statistics, 2019.

Based on the data in Table 1, it shows that the number of hotels in Yogyakarta continues to increase. It can be seen in 2017 the number of star hotels was 82 hotels. In 2018, the number of star hotels in the city of Yogyakarta increased by 90 hotels. In 2019, there was an increase in the number of star hotels in Yogyakarta as many as 163 hotels. This shows an increase in the number of star hotels in Yogyakarta by $49.69 \%$. In addition, 
the increase continued to occur in other accommodation during 2017-2019 amounting to $78.24 \%$. This shows that the increase continues to occur both in the growth of star hotels and other accommodation in Yogyakarta in the $2017-2019$ period of $75.65 \%$. It is predicted that the emergence of new hotels in Yogyakarta will continue to grow. The number of star hotel rooms currently has reached as many as 13,000 rooms and is considered too many, thus making the hotel business unhealthy. Therefore, there is intense competition among hotel entrepreneurs (Deddy, 2020).

Table 2 - Number of 4 Star Hotels in Yogyakarta City

\begin{tabular}{llll}
\hline No & Hotel Name & Address & Rating \\
\hline 1 & Grand Ambarrrukmo Yogyakarta & Jl. Adisucipto No. 82 & 9.0 \\
2 & Swiss-Bellboutique Yogyakarta & Jl. Jend. Sudirman no. 69 & 9.0 \\
3 & Prime Plaza Hotel Jogjakarta & Jl. Afandi & 8.9 \\
4 & Artotel Yogyakarta & Jl. Kaliurang Km 5.6 & 8.9 \\
5 & GAIA Cosmo Hotel & Jl. Ipda Tut Harsono No. 16 & 8.9 \\
6 & Gallery Prawirotaman Hotel & Jl. Prawirotaman 2 & 8.8 \\
7 & Harper Malioboro Yogyakarta & Jl. Mangkubumi No. 52 & 8.8 \\
8 & Grand Dafam Rohan Yogyakarta & Jl. Janti-Gedongkuning No. 336 & 8.8 \\
9 & Royal Darmo Malioboro & Jl. Kemiteren Kidul No. 54 & 8.7 \\
\hline
\end{tabular}

Source: www.traveloka.com, 2019.

Based on the data in Table 2, the total number of 4-star hotels in Yogyakarta is 15 hotels. Based on the online travel agent on the Traveloka.com site, the Grand Ambarrukmo hotel is in the top rank with a rating of 9.0 while the Royal Darmo Malioboro hotel ranks 9 with a rating of 8.7. In addition, when compared to the Harper Malioboro hotel, which is located in the same area, the Royal Darmo Malioboro hotel ranks 7th with a rating of 8.8. This indicates that consumer decisions about the Royal Darmo Malioboro hotel are still low (Traveloka.com, 2019).

Hotel Royal Darmo Malioboro is one of the star hotels located in the city of Yogyakarta. Hotel Royal Darmo Malioboro presents a concept of balance between service quality and price offered, where guests can enjoy excellent service and have a pleasant stay. The location which is in thering firstof the city center of Yogyakarta is an added value, besides making it easier for guests to reach the location, close access to Jl. Malioboro can pamper guests for shopping trips. Hotel Royal Darmo Malioboro has 140 rooms with a choice of 5 room types, 94 superior rooms, 41 deluxe rooms, 2 executive rooms, 2 junior suites and 1 suite, where each room type offers a choice of different prices and facilities. Hotel Royal Darmo Malioboro provides 24-hour reception, fitness, swimming pool, airport shuttle, car parklift, lobby,service laundry, meeting facilities, restaurant, room service, smoking room and wifi.

Table 3 - Sales Target and Actual Room Sales at Hotel Royal Darmo Malioboro, January - December 2019 Period

\begin{tabular}{llll}
\hline Month & Sales Target & Actual Room Sales & Variance \\
\hline January & 1,966 & 1,972 & 6 \\
February & 1,724 & 1,425 & -299 \\
March & 2,597 & 2,279 & -318 \\
April & 3,640 & 3,031 & -609 \\
May & 1,566 & 728 & -838 \\
June & 2,285 & 2,495 & -838 \\
July & 3,117 & 2,771 & -346 \\
August & 3,338 & 2,066 & $-1,272$ \\
September & 3,804 & 2,394 & $-1,410$ \\
October & 3,738 & 2,441 & $-1,297$ \\
November & 4,148 & 2,928 & $-1,220$ \\
December & 4,596 & 4,356 & -240 \\
\hline
\end{tabular}

Source: Sales \& Marketing Department of Hotel Royal Darmo Malioboro, 2019. 
Based on data in Table 3, it can be seen that during the last 12 months of room sales carried out by Hotel Royal Darmo Malioboro, there were several months that could not reach the set target. In September 2019, the room sales target was 3,804 rooms while the achievement was only 2,394 rooms, so it can be seen that the difference between the target and the actual is 1,410 rooms. In connection with the problems that occurred, the hotel has carried out various advertising activities such as through social media, newspapers, brochures / flyers, billboards and others.

The development of business in Indonesia is a very interesting phenomenon to study, especially in the era of globalization, especially in an increasingly open economy. This opens up opportunities for entrepreneurs to compete in attracting consumers. The impact of globalization has caused the hotel service industry to face intense competition and experience rapid growth and development. This condition spurs companies to further increase their role in serving consumers. This happened at the Royal Darmo Malioboro Hotel, which shows the condition of not achieving the room sales target, it is suspected that the advertising activities that have been carried out by Hotel Royal Darmo Malioboro are still not optimal and by looking at the phenomenon based on the rating obtained by Hotel Royal Darmo Malioboro which still occupies the lowest position. With this, it makes researchers interested in conducting research at Hotel Royal Darmo Malioboro.

The increasing number of new hotels exposes consumers to a variety of choices and different types of hotels. Choices that are very diverse require consumers to be more careful in deciding their choice. One of the factors that are considered by consumers to make a purchase is advertising. According to (Kotler \& Armstrong, 2012), advertising is all forms of non-personal presentation and promotion of ideas, goods or services by a certain sponsor that requires payment. Another factor that can influence consumer decisions in making purchases is service quality. Service quality is an important determinant of customer satisfaction and will directly affect the success of a company. Service quality is a customer assessment of the superiority or features of a product or service as a whole (Parasuraman, A. Zeithaml, \& L. Berry, 1990).

Problem Formulation:

- How does advertising influence consumer decisions to stay at Hotel Royal Darmo Malioboro Yogyakarta?

- How is the effect of service quality on consumer decisions to stay at Hotel Royal Darmo Malioboro Yogyakarta?

Objective of study:

- To compare with similar competitors and seek empirical evidence by analyzing the effect of advertising on consumer decisions to stay at the Royal Darmo Malioboro Hotel Yogyakarta;

- To compare with similar competitors and seek empirical evidence by analyzing the effect of service quality on consumer decisions to stay at Hotel Royal Darmo Malioboro Yogyakarta.

\section{LITERATURE REVIEW}

Decisions are a stage where consumers have a choice and are ready to make a purchase or exchange between money and a promise to pay with ownership rights or use of a good or service (Kotler \& Keller, 2016). Dimensions of purchasing decisions according to (Kotler \& Keller, 2016) are divided into six dimensions that affect purchasing decisions, namely: 1) product selection decisions, 2) selected brand decisions, 3) selected store decisions, 4) decisions regarding quantities, 5) decisions regarding the selected purchase time, and 6) decisions regarding the method of payment.

Advertising (advertising) is any form of presentation and promotion of ideas, goods or services nonpersonal by a particular sponsor that require payment (Kotler \& Armstrong, 2012). Advertising (advertising) has a non-personal nature and is a tool to promote products or services without making direct contact and the advertiser must pay a certain rate. According to (Kotler \& Keller, 2016), the dimensions of advertising are divided into 3, namely 
as follows: 1) the purpose (mission), 2) the message conveyed (message), 3) the media used (media).

Service quality is a customer assessment of the superiority or features of a product or service as a whole (Parasuraman et al., 1990). One model of service quality that is widely used as a reference in marketing research is the model service quality. Service quality is built on the existence of a comparison of two main factors, namely customer perceptions of the real service they receive with the actual service they expect and want. The dimensions of service quality according to (Parasuraman \& Zeithaml, 1985) are divided into 5, namely: 1) tangible (physical evidence), 2) empathy (empathy), 3) reliability, 4) responsiveness (responsiveness), 5) assurance (guarantee).

\section{METHODS OF RESEARCH}

The population in this study is all consumers who stay at Hotel Royal Darmo Malioboro Yogyakarta at least more than 1 night. The number of the population in this study is unknown, so to calculate the minimum sample size needed, the formula is used Lemeshow for an unknown population (Snedecor \& Chocran, 2015). Based on the Leme show formula, the $n$ obtained is 96.04 so that in this study at least the researcher must take data from a sample of at least 100 consumers who have stayed at Hotel Royal Darmo Malioboro Yogyakarta. The sampling technique in this study used a method non-probability sampling. Respondents selected in this study were guests who had stayed more than 1 night at the Royal Darmo Malioboro Hotel in the period 2020.

\section{RESULTS AND DISCUSSION}

Table 4 displays the results of the validity test for 30 respondents in the research variables as follows:

Table 4 - Results of the Validity Test

\begin{tabular}{llllll}
\hline Indicator & $\begin{array}{l}\text { Product Moment } \\
\text { Pearson's }\end{array}$ & Sig. & & $\alpha$ & Information \\
\hline X1.1 & 0.532 & 0.002 & $<$ & 0.05 & Valid \\
X1.2 & 0.602 & 0.000 & $<$ & 0.05 & Valid \\
X1.3 & 0.384 & 0.036 & $<$ & 0.05 & Valid \\
X1.4 & 0.740 & 0.000 & $<$ & 0.05 & Valid \\
X1.5 & 0.647 & 0.000 & $<$ & 0,05 & Valid \\
X2.1 & 0.868 & 0.000 & & $<0.05$ & Valid \\
X2.2 & 0.662 & 0.000 & & $<0.05$ & Valid \\
X2.3 & 0.684 & 0.000 & & $<0.05$ & Valid \\
X2.4 & 0.475 & 0.008 & & $<0.05$ & Valid \\
X2.5 & 0,800 & 0,000 & & $<0,05$ & Valid \\
Y.1 & 0.755 & 0.000 & & $<0.05$ & Valid \\
Y.2 & 0.712 & 0.000 & & $<0.05$ & Valid \\
Y.3 & 0.373 & 0.043 & & $<0.05$ & Valid \\
Y.4 & 0.625 & 0.000 & & 0.05 & Valid \\
Y.5 & $<0.739$ & 0.000 & $<0$, & 05 & Valid \\
\hline
\end{tabular}

Data Sources: Processed from the Questionnaire, 2020.

Based on Table 4 it is known that each indicator (item) in each variable of product quality and service quality which is an independent variable on purchasing decisions which is the dependent variable has the result of Pearson's product moment value with a value significance $<0.05$, so that the indicators (items) used in this research variable can be declared appropriate or relevant and can be used as items in data collection.

Based on the results of the reliability test in Table 5 , the results of the reliability test for the independent variable of advertising (X1) and service quality (X2) show that the data obtained is reliable because the values are cronbach's alpha 0.728 and 0.779 while the 
variable reliability test results dependent on consumer decisions $(Y)$ indicates that the data obtained is reliable because the value Cronbach's alphais 0.759 .

Table 5 - Reliability Test Results

\begin{tabular}{lllll}
\hline Variable & Cronbach's Alpha & Cutt Off & N of Item & Information \\
\hline Advertising (X1) & 0.728 & $>0.60$ & 5 & Reliable \\
Service Quality (X2) & 0.779 & $>0.60$ & 5 & Reliable \\
Consumer Decisions (Y) & 0.759 & $>0.60$ & 5 & Reliable \\
\hline
\end{tabular}

Data Sources: Processed from the Questionnaire, 2020.

Table 6 - Profile of Research Respondents

\begin{tabular}{llll}
\hline No & Gender & $\begin{array}{l}\text { Frequency } \\
\text { (Person) }\end{array}$ & $\begin{array}{l}\text { Percentage } \\
(\%)\end{array}$ \\
\hline 1 & Male & 73 & 73.0 \\
2 & Female & 27 & 27.0 \\
\hline & Total & 100 & 100 \\
\hline \multirow{2}{*}{ No } & Age & Frequency & Percentage \\
& (Years) & (Person) & $19)$ \\
\hline 1 & $<30$ & 19 & 44.0 \\
2 & $31-40$ & 44 & 34.0 \\
3 & $41-50$ & 34 & 3.0 \\
4 & $>50$ & 3 & 100 \\
\hline & Total & 100 & Percentage \\
\multirow{2}{*}{ No } & Education & Frequency & $(\%)$ \\
\hline 1 & SMA & (Person) & 10.0 \\
2 & Diploma & 10 & 16.0 \\
3 & S1 / S2 & 16 & 71.0 \\
4 & Others & 71 & 3.0 \\
\hline & Total & 3 & 100 \\
\hline
\end{tabular}

Data Source: Processed from the Questionnaire, 2020.

Based on Table 6, the dominant gender of the respondents was 73 men with a percentage of $73 \%$. Meanwhile, the minority of respondents were women who became respondents with a total of 27 people or about $27 \%$.

The age of the most respondents or the majority were respondents aged between 31 40 years, amounting to 44 people with a percentage of $44 \%$, while respondents who were a minority age were those aged $>50$ years, amounting to 3 people with a percentage of $3 \%$.

The education level of the respondents with the most or the majority were respondents in the S1 / S2 education level category, amounting to 71 people with a percentage of $71 \%$, while the minority were respondents with other education level categories totaling 3 people with a percentage of $3 \%$.

Respondents' responses related to advertising variables will provide an overview of the extent of advertising at Hotel Royal Darmo Malioboro Yogyakarta. The advertising variable is represented by five question items. The respondent's opinion on the advertising variable items can be explained in Table 7.

It shows that the advertising variables on the promotional indicators carried out by the Royal Darmo Malioboro Hotel are often encountered in electronic media shows the lowest value, namely sebesa $r$ 3.20. It is suspected that advertisements for Hotel Royal Darmo Malioboro Yogyakarta are still rare to find in electronic media. On the hotel indicator, Royal Darmo Malioboro provides promo prices that are very attractive to consumers, showing the highest score of 4.63. This shows that the promo price bidding given greatly influences consumer interest in staying overnight. Thus, the total average score for the advertising variable is 3.82 and is included in the "Good" category.

Respondents' responses related to service quality variables will provide an overview of the extent to which the quality of service provided by Hotel Royal Darmo Malioboro 
Yogyakarta. The service quality variable is represented by five question items. The respondent's opinion on the items of service quality variable can be explained in the Table 8 .

Table 7 - Respondents' Responses to Advertising Variables (X1)

\begin{tabular}{|c|c|c|c|c|c|c|c|c|c|}
\hline Variable & Statement & $\begin{array}{l}\text { STS } \\
(1) \\
\%\end{array}$ & $\begin{array}{l}\text { TS } \\
(2) \\
\%\end{array}$ & $\begin{array}{l}N \\
(3) \\
\%\end{array}$ & $\begin{array}{l}\mathrm{S} \\
(4) \\
\%\end{array}$ & $\begin{array}{l}\text { SS } \\
(5) \\
\%\end{array}$ & Number & Average & Interpretations \\
\hline $\mathrm{X} 1.1$ & $\begin{array}{l}\text { Offers given Hotel Royal Darmo } \\
\text { Malioboro Has an attraction for } \\
\text { consumers to stay }\end{array}$ & 0 & 1 & 26 & 68 & 5 & 100 & 3.77 & Good \\
\hline $\mathrm{X} 1.2$ & $\begin{array}{l}\text { The offers of Hotel Royal } \\
\text { Darmo Malioboro are very } \\
\text { attractive }\end{array}$ & 0 & 1 & 29 & 59 & 11 & 100 & 3.80 & Good \\
\hline $\mathrm{X} 1.3$ & $\begin{array}{l}\text { Hotel Royal Darmo Malioboro } \\
\text { provides prices promotions that } \\
\text { are very attractive to consumers }\end{array}$ & 0 & 0 & 2 & 33 & 65 & 100 & 4.63 & Very good \\
\hline $\mathrm{X} 1.4$ & $\begin{array}{l}\text { Promotions carried out by Hotel } \\
\text { Royal Darmo are often found in } \\
\text { print media }\end{array}$ & 0 & 3 & 34 & 52 & 11 & 100 & 3.71 & Good \\
\hline $\mathrm{X} 1.5$ & $\begin{array}{l}\text { Promotions carried out by Hotel } \\
\text { Royal Darmo often found in } \\
\text { electronic media }\end{array}$ & 0 & 9 & 65 & 23 & 3 & 100 & 3.20 & Good \\
\hline Average & & & & & & & 100 & 3.82 & Good \\
\hline
\end{tabular}

Data Source: Processed from the Questionnaire, 2020.

Table 8 - Respondents' Responses to Service Quality Variables (X2)

\begin{tabular}{|c|c|c|c|c|c|c|c|c|c|}
\hline Variable & Statement & $\begin{array}{l}\text { STS } \\
(1) \\
\%\end{array}$ & $\begin{array}{l}\text { TS } \\
(2) \\
\%\end{array}$ & $\begin{array}{l}\mathrm{N} \\
(3) \\
\%\end{array}$ & $\begin{array}{l}\text { S } \\
(4) \\
\%\end{array}$ & $\begin{array}{l}\text { SS } \\
(5) \\
\%\end{array}$ & Number & Average & Interpretations \\
\hline $\mathrm{X} 2.1$ & $\begin{array}{l}\text { Buildings and facilities of Royal } \\
\text { Darmo Hotel Malioboro is in } \\
\text { good condition }\end{array}$ & 0 & 4 & 42 & 34 & 20 & 100 & 3.70 & Good \\
\hline$X 2.2$ & $\begin{array}{l}\text { Royal Darmo Malioboro Hotel } \\
\text { staff can be relied on in } \\
\text { handling problems }\end{array}$ & 0 & 0 & 15 & 49 & 36 & 100 & 4.21 & Good \\
\hline X2.3 & $\begin{array}{l}\text { Royal Darmo Hotel staff } \\
\text { Malioboro treats consumers } \\
\text { with friendly sincerity }\end{array}$ & 0 & 0 & 12 & 46 & 42 & 100 & 4.30 & Very good \\
\hline X2.4 & $\begin{array}{l}\text { Hotel employees of Royal } \\
\text { Darmo Malioboro are ready to } \\
\text { help consumers } 24 \text { hours }\end{array}$ & 0 & 0 & 0 & 15 & 85 & 100 & 4.85 & Very good \\
\hline X2.5 & $\begin{array}{l}\text { Hotel Royal Darmo Malioboro } \\
\text { makes consumers feel safe and } \\
\text { comfortable in stay }\end{array}$ & 0 & 0 & 8 & 52 & 40 & 100 & 4.32 & Very Good \\
\hline Average & & & & & & & 100 & 4.27 & Very Good \\
\hline
\end{tabular}

Data Source: Processed from the Questionnaire, 2020.

Based on Table 8 shows that the service quality variables on the building indicators and facilities of the Royal Darmo Malioboro Hotel are in good condition shows the lowest value of 3.70 . It is suspected that consumers still feel that the buildings and facilities at Hotel Royal Darmo Malioboro are still not very good. On the indicators, employees of Hotel Royal Darmo Malioboro are ready to help consumers 24 hours showing the highest score of 4.85 . This shows that the services provided by Hotel Royal Darmo Malioboro in helping consumers can be available 24 hours. Thus, the total average skpr value on the service quality variable was 4.27 and included in the "Very Good" category.

Respondents' responses related to consumer decision variables to stay at Hotel Royal Darmo Malioboro Yogyakarta. The consumer decision variable is represented by five question items. The respondent's opinion on the consumer decision variable items can be explained in the Table 9: 
Table 9 - Respondents' Responses to Consumer Decision Variables (Y)

\begin{tabular}{|c|c|c|c|c|c|c|c|c|c|}
\hline Variables & Statement & $\begin{array}{l}\text { STS } \\
(1) \\
\% \\
\end{array}$ & $\begin{array}{l}\text { TS } \\
(2) \\
\% \\
\end{array}$ & $\begin{array}{l}\mathrm{N} \\
(3) \\
\% \\
\end{array}$ & $\begin{array}{l}\mathrm{S} \\
(4) \\
\% \\
\end{array}$ & $\begin{array}{l}\text { SS } \\
(5) \\
\%\end{array}$ & Number & Averageof & Interpretations \\
\hline Y.1 & $\begin{array}{l}\text { I am interested in staying at } \\
\text { hotels Royal Darmo Malioboro }\end{array}$ & 0 & 1 & 6 & 35 & 58 & 100 & 4.50 & Very Good \\
\hline Y.2 & $\begin{array}{l}\text { I am satisfied with the services } \\
\text { provided by Hotel Royal } \\
\text { Darmo Malioboro }\end{array}$ & 0 & 1 & 8 & 40 & 51 & 100 & 4.41 & Very good \\
\hline Y.3 & $\begin{array}{l}\text { Hotel Royal Darmo Malioboro } \\
\text { has a good image among } \\
\text { community }\end{array}$ & 0 & 0 & 1 & 8 & 91 & 100 & 4.90 & Good \\
\hline Y.4 & $\begin{array}{l}\text { Reservations for Hotel Royal } \\
\text { Darmo Malioboro can be made } \\
\text { online or offline }\end{array}$ & 0 & 0 & 5 & 42 & 53 & 100 & 4.48 & Very good \\
\hline Y.5 & $\begin{array}{l}\text { There are several payment } \\
\text { systems at Hotel Royal Darmo } \\
\text { Malioboro and provide direct } \\
\text { discounts to consumers }\end{array}$ & 0 & 3 & 36 & 39 & 22 & 100 & 3.80 & Good \\
\hline Average & & & & & & & 100 & 4.41 & Very good \\
\hline
\end{tabular}

Data source: Processed from the questionnaire, 2020.

Based on Table 9 shows that in the consumer decision variable on the indicator there are several payment systems at the Royal Hotel Darmo Malioboro and gives a direct discount to consumers shows the lowest value of 3.80. It is assumed that not all payment systems provide discounts to consumers. The indicator for Hotel Royal Darmo Malioboro has a good image among the public, showing the highest value of 4.90. It is assumed that the good image makes Hotel Royal Darmo Malioboro one of the choices for consumers to stay. Thus, the total average score of the purchasing decision variable is 4.41 and is included in the "Very Good" category.

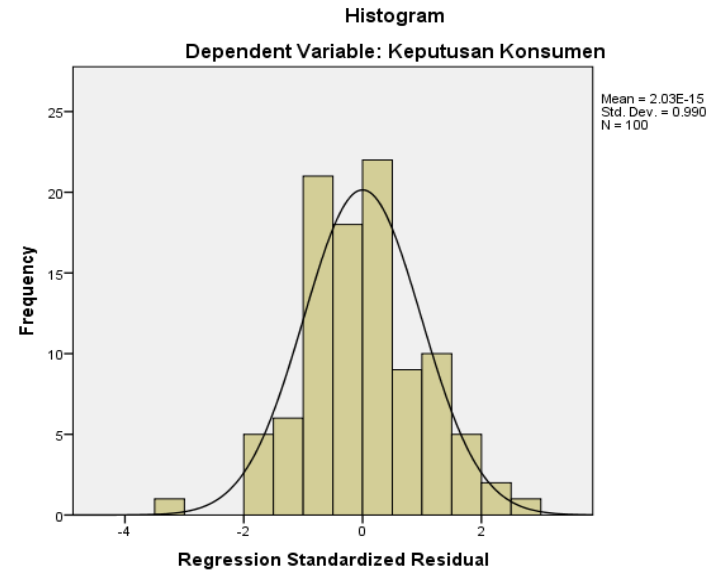

Figure 1 - Results of Normality Test (Data Source: Processed from the Questionnaire, 2020)

Based on Figure 1, it can be seen that the distribution pattern is close to normal, but if the conclusion is normal or not the data is only seen from the histogram graph, then this can be misleading, especially for a small number of samples. Another method used in graph analysis is to look at the normal probability plot that compares the cumulative distribution of the normal distribution. If the distribution of the residual data is normal, then the line that represents the actual data will follow the diagonal line.

Based on the results of the normality test in Table 10, it shows that the data has been normally distributed. This is indicated by the test Kolmogorov-Smirnov which shows the results which have a significance level of 0.199 which is above 0.05 . 


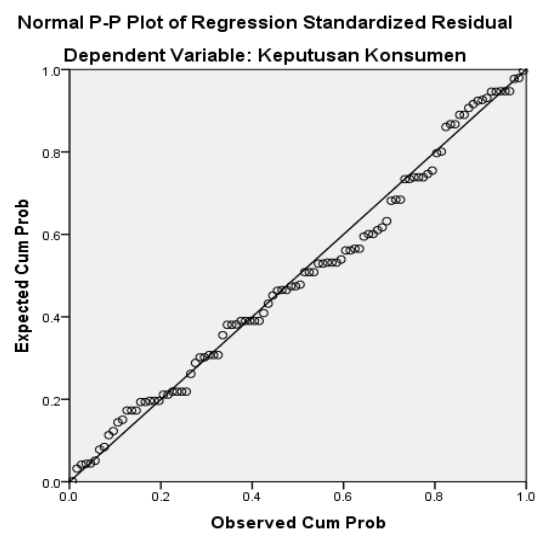

Figure 2 - Normal Probability Plot (Data source: Processed from questionnaires, 2020)

Table 10 - Results of the Kolmogorov-Smirnov One-Sample Normality Test

\begin{tabular}{lll}
\hline & & Unstandardized Residual \\
\hline $\mathrm{N}$ & & 100 \\
Normal Parameters & Mean & .0000000 \\
& Std. Deviation & .57004199 \\
Most Extreme Difference & Absolute & .074 \\
& Positive & .074 \\
Kolmogrov-Smirnov Z & Negative & -.050 \\
Asymp. Sig. (2-tailed) & & .074 \\
\hline
\end{tabular}

Data Source: Processed from the Questionnaire, 2020.

Table 11 - Multicollinearity Results

\begin{tabular}{lllll}
\hline Test Of Multicollinearity & VIF & & Cut Off & Information \\
\hline Advertising & 1.739 & $<$ & 10 & Multicollinearity Not Occurring \\
Service Quality & 1.739 & $<$ & 10 & Multicollinearity Not Occurring \\
\hline
\end{tabular}

Data Source: Processed from the Questionnaire, 2020.

Based on the results of Table 11 shows that multicollinearity does not occur between independent variables because it shows a VIF less than 10. Thus in this model there is no multicollinearity problem.

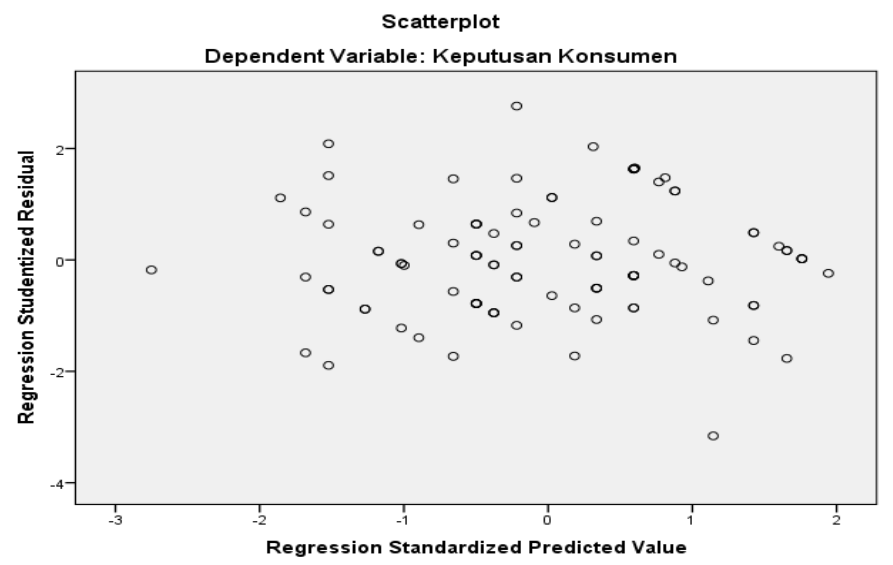

Figure 3 - The results of the Heteroscedasticity Test (Data Source: Processed from Questionnaires, 2020)

Based on Figure 3, it shows that there is no heteroscedasticity, because the data distribution does not form a certain line or there is no clear pattern, and the points spread above and below the zero on the $\mathrm{Y}$ axis. 
Multiple linearity analysis was conducted to determine the effect of advertising variables (X1) and service quality (X2) on consumer decisions (Y). Based on the test results obtained as follows:

Table 12 - Results of Multiple Linear Regression Analysis

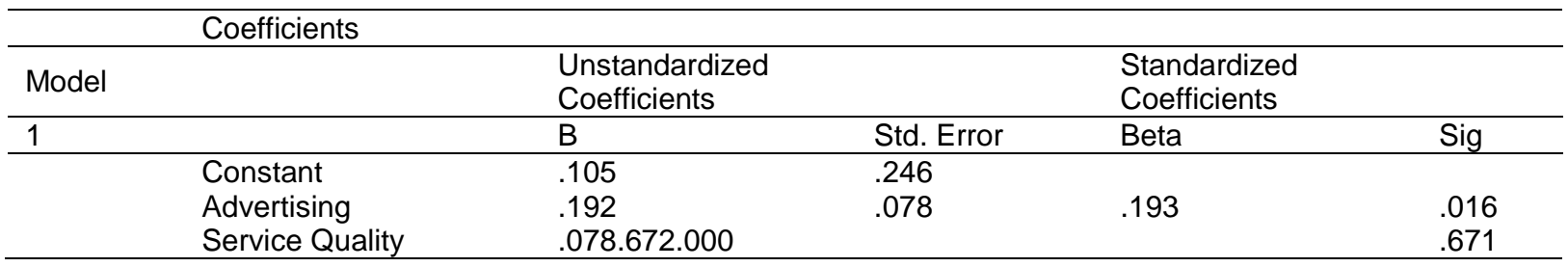

Source: Adapted from Questionnaire, 2020.

Based on Table 12, the results of multiple linear regression analysis can be expressed by the equation as follows:

$$
Y=0.105+0.192 X_{1}+0.671 X_{2}+\mathrm{e}
$$

The linear regression equation above can be explained as follows:

- The constant value indicates a positive value with a value of 0.105 . This shows that the consumer's decision to stay at Hotel Royal Darmo Malioboro Yogyakarta is considered that without the influence of advertising and service quality, the magnitude of the consumer decision variable is 0.105 ;

- The regression coefficient value of the advertising variable is 0.192 , which states that advertising has a positive effect on consumer decisions. This shows that the higher the advertising, the positive impact, namely the higher the consumer's decision to stay at Hotel Royal Darmo Malioboro Yogyakarta;

- The regression coefficient value of the service quality variable is 0.671 which states that service quality has a positive effect on consumer decisions. This shows that the higher the quality of service provided, the positive impact, namely the higher the consumer's decision to stay at Hotel Royal Darmo Malioboro Yogyakarta.

Table 13 - Test Results Correlation Coefficient $(r)$ and Coefficient of Determination $\left(R^{2}\right)$

\begin{tabular}{lllll}
\multicolumn{4}{l}{ Model Summary } \\
\hline Model & $\mathrm{R}$ & $\mathrm{R}$ Square & Adjusted R Square & Std. Error of the Estimate \\
\hline 1 & .810 & .657 & .650 & .575889 \\
\hline
\end{tabular}

Data Source: Processed from the Questionnaire, 2020.

Based on the output model summary in Table 13, the results of the correlation coefficient $(r)$ test show that the magnitude of the influence of advertising variables and service quality on consumer decisions is equal to 0.810 or $81.0 \%$. The magnitude of the numbers $\mathrm{R}$ square $\left(R^{2}\right)$ is 0.657 or $65.7 \%$, the figure is used to see how the advertising and service quality affects the consumer's decision to stay at the Hotel Royal Darmo Malioboro.

Table 14 - Test Results of Significance of Individual Parameters (t test)

\begin{tabular}{lllllll}
\hline Coefficients & \multicolumn{3}{l}{} & & \\
\hline Model & & $\begin{array}{l}\text { Unstandardized } \\
\text { Coefficients }\end{array}$ & & $\begin{array}{l}\text { Standardized } \\
\text { Coefficients }\end{array}$ & $\mathrm{t}$ & Sig. \\
\hline 1 & $\mathrm{~B}$ & $\begin{array}{l}\text { Std. Error } \\
\text { (Constant) }\end{array}$ & .105 & Beta & & \\
& Advertising & .192 & .246 & & .425 & .671 \\
& Services Quality & $.078 .6728,563.000$ & .078 & .193 & 2455 & .016 \\
& & & & & .671 \\
\hline
\end{tabular}

Source: Adapted from Questionnaire, 2020. 
This figure means that how the advertising and service quality variables show the factors that influence consumer decisions to stay at the Royal Darmo Malioboro Hotel Yogyakarta and together it is $65.7 \%$ while the remaining $34.3 \%$ is influenced by other factors such as corporate image, promotions, prices and more.

The significance test for individual parameters (t test) aims to determine how much influence the independent variables individually have on the dependent variable. This study has a significance of $5 \%$ or $\alpha=0.05$. The results of the t test can be seen in Table 14 .

Based on the analysis calculation on Table 14, can be described as follows:

1. Advertising variable (X1), has a beta value of 0.192 with a significant value of 0.016 which is smaller than 0.05 . This shows that the advertising variable has a positive and significant influence on consumer decisions to stay at the Royal Darmo Hotel Yogyakarta. This proves that the first hypothesis on the advertising variable has a positive and significant effect is acceptable;

2. The service quality variable (X2), has a beta of 0.671 with a significance value of 0.000 which is smaller than 0.05 . This shows that the variable service quality has a positive and significant influence on consumer decisions to stay at the Royal Darmo Hotel Yogyakarta. This proves that the second hypothesis on the variable service quality has a positive and significant effect is acceptable.

\section{DISCUSSION OF RESULTS}

The Effect of Advertising on Consumer Decisions to Stay at Hotel Royal Darmo Malioboro Yogyakarta. Advertising has a positive and significant effect on consumer decisions. The results of this study are in line with the results of research (Pertiwi \& Pradhanawati, 2020); (Main, 2020); (Huda \& Nurchayati, 2018); (Isyanahapsari, 2017); (Lee \& Anjarwati, 2017); (Poluan, Lumintang, \& Untu, 2016); (Sriyanto \& Utami, 2016); (Alfan, 2016); (Isyanahapsari, 2016); (Permatasari, Fauzi, \& Yulianto, 2015); (Sandy, Arifin, \& Yaningwati, 2015); (Togas, Sepang, \& Wenas, 2015) show that advertising has a positive and significant effect on consumer decisions.

Advertising(advertising)is any form of presentation and promotion of ideas, goods or services nonpersonal by a particular sponsor that require payment (Kotler \& Armstrong, 2012). Although advertising does not directly affect purchasing decisions, advertising is a means to help effective marketing to establish communication between companies and consumers in facing competitors (Kotler \& Keller, 2003). Good advertising creativity can support high advertising effectiveness. Therefore, a good advertising concept is needed so that communication between companies and consumers can run well. The more attractive the advertisement is, the more it will increase consumer attractiveness to improve purchasing decisions. Advertising can be a source of consumer information before consumers make a purchase decision. In advertisements, there is a variety of information that describes the advantages and information of a particular product or service that can make consumers make purchases (Kotler \& Armstrong, 2012).

The results of this study indicate that advertising is associated with several indicators such as the purpose (mission), the message conveyed (message), the media used (media). The indicator "Hotel Royal Darmo Malioboro Yogyakarta provides promo prices that are very attractive to consumers" shows the highest score. This shows that the promo price bidding given greatly influences consumer interest in staying overnight. By providing this attractive promo, it will make the main attraction of potential consumers to stay. One form of promotion that is very attractive to consumers is direct discounting, additional dining facilities and other facilities available at the hotel.

The indicator "promotions conducted by Hotel Royal Darmo Malioboro are often found in electronic media" shows the lowest value. It is suspected that advertisements for Hotel Royal Darmo Malioboro Yogyakarta are still rare to find in electronic media. Based on the results of questionnaires that have been distributed to consumers at Hotel Royal Darmo Malioboro Yogyakarta, it shows that consumers are still very rare to find promotions held by 
hotels in electronic media. In this digital era, promotion through electronic media needs to be done attractively to attract consumers through electronic media.

The Influence of Service Quality on Consumer Decisions to Stay at the Royal Darmo Malioboro Hotel Yogyakarta. Service quality has a positive and significant effect on consumer decisions. These results are in line with research results from (Wulandari \& Widayanto, 2020); (Demanda, 2018); (Adyanto \& Santosa, 2018b); (Febriani, 2018); (Faruq, 2018); (Hanifati \& Waluyo, 2018); (Radjapati, Tumbuan, \& Soepeno, 2018); (Hanifati \& Waluyo, 2018); (Rafi \& Budiatmo, 2018); (Utomo \& Waluyo, 2018); (Isyanahapsari, 2017); (Vatjanasaregagu \& Thammathira, 2017); (Adyanto, 2017); (Jundi, 2016); (Isyanahapsari, 2016) found that service quality has a positive and significant effect on consumer decisions.

The second factor that influences purchasing decisions is service quality. Service quality is also one of the important factors that must be done by companies to get the attention of consumers, with the promising service quality that is expected to encourage consumer decisions. Service quality (service quality) is a customer assessment of the superiority or features of a product or service as a whole (Parasuraman et al., 1990). In the service business, service quality plays an important role in providing added value to the overall experience. In formulating service strategies and programs, every business actor must be oriented towards the interests of customers and pay great attention to quality. This is very important so that customers do not give up their intention when making a purchase decision (Lumberg, 2006).

The quality of services provided is associated with the dimensions of physical evidence (tangible), empathy (empathy), responsiveness (responsiveness), and assurance (assurance). Based on the research results, it shows that the dimension of assurance (assurance) shows the highest average score against consumer decisions. Service quality that affects consumer decisions can be interpreted as meeting the needs and desires of consumers and the accuracy of their delivery in balancing consumer expectations. On the indicators, employees of Hotel Royal Darmo Malioboro Yogyakarta are ready to help consumers 24 hours to show the highest score. This shows that the services provided by Hotel Royal Darmo Malioboro in helping consumers can be available 24 hours. The building indicators and facilities of the Royal Darmo Malioboro Hotel in good condition show the lowest value. It is suspected that consumers still feel that the buildings and facilities at Hotel Royal Darmo Malioboro Yogyakarta are still not very good.

\section{CONCLUSION}

Advertising has a positive and significant effect on consumer decisions to stay at Hotel Royal Darmo Malioboro Yogyakarta. Service quality has a positive and significant effect on consumer decisions to stay at Hotel Royal Darmo Malioboro Yogyakarta.

Suggestions:

a. In the advertising variable, it is hoped that more frequent advertisements can be placed on electronic media, which in this digital era, electronic media is one of the most important places for promotion. Hotel Royal Darmo Malioboro Yogyakarta needs to manage employees who can broadcast on social media. Promotions on social media and attractive online hotel booking sites as well as attractive offers will provide a special attraction for consumers to decide to stay at Hotel Royal Darmo Malioboro Yogyakarta;

b. In terms of service quality variables, Hotel Royal Darmo Malioboro Yogyakarta should carry out routine maintenance of the building and other hotel facilities. Besides, hotel design updates that need to be adapted to the times but do not eliminate the original elements of the hotel will be able to provide comfort for consumers in their stay. Besides, management in improving cleanliness and hotel facilities such as checking electronic devices and items in other hotel rooms is very necessary to carry out routine checks so that consumers who stay will be comfortable and satisfied with the quality of service provided by Hotel Royal Darmo Malioboro Yogyakarta. in providing services. 


\section{REFERENCES}

1. Adyanto, BC (2017). Pengaruh Kualitas Layanan, Brand Image, Harga and Kepercayaan Produk Terhadap Keputusan Pembelian (Studi Kasus E-Commerce Berrybenka.com). Jurnal Universitas Diponegoro.

2. Adyanto, BC, \& Santosa, SB (2018). Pengaruh Kualitas Layanan, Brand Image, Harga and Kepercayaan Produk Terhadap Keputusan Pembelian (Studi Layanan E-Commerce Berrybenka.com). Diponegoro Journal of Social and Politics, Vol. 7 (1)(ISSN (Online): 2337-3792), 1-20.

3. Alfan, MF (2016). Pengaruh Periklanan Terhadap Keputusan Konsumen Menggunakan Jasa Pariwisata Mekar Jaya Abadi di Sidoarjo. Jurnal Universitas Negeri Surabaya.

4. Andryusalfikri, Wahab, Z., \& Widiyanti, M. (2019). Effect of Trust, Quality of Product and Quality Services on Purchase Decisions on E-Commerce Shopee in Palembang City. International Journal of Management and Humanities (IJMH), Vol. 3(ISSN: 2394-0913).

5. Demanda, FO (2018). Pengaruh Kualitas Produk, Kualitas Pelayanan and Kepuasan Pelanggan Terhadap Keputusan Pembelian di Throwback Coffee + Kitchen Cikarang. Jurnal President University.

6. Faruq, U. (2018). Analisis Pengaruh Electronic Word of Mouth, Kualitas Pelayanan, Harga and Citra Merek Terhadap Keputusan Pembelian Pada Situs E-Commerce (Studi pada Zalora Indonesia di Semarang). Jurnal Universitas Diponegoro.

7. Febriani, RR (2018). Pengaruh Brand Image and Kualitas Layanan Terhadap Kepercayaan and Keputusan Pembelian Pada Toko Online (Studi pada Konsumen OLX.co.id di Kota Semarang). Jurnal Universitas Diponegoro.

8. Hanifati, F., \& Waluyo, HD (2018a). Pengaruh Harga, Brand Image and Kualitas Pelayanan Terhadap Keputusan Pembelian (Studi Kasus Gracia Skin Clinic Semarang). Diponegoro Journal of Social and Politc, 1-5.

9. Hanifati, F., \& Waluyo, HD (2018). Pengaruh Harga, Brand Image and Kualitas Pelayanan Terhadap Keputusan Pembelian (Studi Kasus Gracia Skin Clinic Semarang). Diponegoro Journal of Social and Politics, 1-5.

10. Huda, N., \& Nurchayati. (2018). Pengaruh Atribut Produk, Iklan, Harga and Kebutuhan Mencari Variasi Terhadap Keputusan Perpindahan Merek Ke Yamaha NMAX di Semarang Selatan. Jurnal IImiah, Vol. 7 No.(ISSN: 2302:2752).

11. Isyanahapsari, S. (2016). Pengaruh Periklanan and Kualitas Pelayanan Terhadap Keputusan Pembelian Secara Online Pada Situs Belanja Online (Studi Kasus pada Pengguna E-commerce Elevenia Di Kota Semarang). Jurnal Universitas Diponegoro.

12. Isyanahapsari, S. (2017). Pengaruh Periklanan and Kualitas Pelayanan Terhadap Keputusan Pembelian Secara Online Pada Situs Belanja Online (Studi Kasus pada Pengguna E-commerce Elevenia Di Kota Semarang). Jurnal Universitas Diponegoro.

13. Jundi, MS (2016). Analisis Pengaruh Kualitas Layanan, Citra Merek and Kepercayaan Terhadap Keputusan Pembelian Melalui Nilai yang Dipersepsikan Sebagai Mediasi Pada Toko Online Lazada. co.id (Studi pada Konsumen Lazada.co.id Kota Semarang). Jurnal Universitas Diponegoro.

14. Kotler, P., \& Keller, KL (2016). Marketing Management (15th ed.). Pearson Education, Inc.

15. Lee, NC, \& Anjarwati, AL (2017). Pengaruh Kualitas Produk and Periklanan Terhadap Keputusan Pembelian the Botol Sosro Kemasan Pet 450 ML (Studi Pada Pengunjung Minimarket di Surabaya Selatan). Jurnal Ilmu Manajemen, Vol. 5 (4).

16. Parasuraman, A., A. Zeithaml, V., \& L. Berry, L. (1990). Delivering Quality Service: Balancing Customer Perception and Expectation. New York: The Free Press.

17. Parasuraman, A., \& Zeithaml, B. (1985). A Conceptual Model of Service Quality and Its Imp;ication for Future Research. Journal Of Marketing, Vol. 49, 41-50.

18. Permatasari, YR, Fauzi, A., \& Yulianto, E. (2015). Pengaruh Periklanan Terhadap Faktor Psikologis Yang Berdampak Terhadap Keputusan Pembelian (Survei pada Mahasiswa Jurusan Administrasi Bisnis Fakultas Ilmu Administrasi Angkatan 2011/2012 and 2012/2013 Universitas Brawijaya Malang yang Membeli Provider XL. Jurnal Administrasi 
Bisnis (JAB), Vol. 8 (2).

19. Pertiwi, ESS, \& Pradhanawati, A. (2020). Pengaruh Kualitas Produk and Iklan Terhadap Keputusan Pembelian Kosmetik Wardah Melalui Citra Merek Sebagai Variabel Intervening (Studi Pada Mahasiswa Aktif Fisip UNDIP). Jurnal Universitas Diponegoro.

20. Poluan, JG, Lumintang, GG, \& Untu, VN (2016). Pengaruh Periklanan Terhadap Keputusan Pembelian Minuman Coca Cola (Studi Kasus Pada PT. Bangun Wenang Beverage Company Manado). Jurnal EMBA, Vol. 4 (3)(ISSN 2303-1174), 671-681.

21. Radjapati, TY, Tumbuan, WJF., \& Soepeno, D. (2018). Pengaruh Periklanan, Promosi Penjualan and Personal Selling Terhadap Keputusan Pembelian Kartu Telkomsel di Tobelo. Jurnal EMBA, Vol. 6 (4)(ISSN 2303-1174), 2428 - 2437.

22. Rafi, M., \& Budiatmo, A. (2018). Pengaruh Kualitas Produk, Kualitas Pelayanan, and Harga Terhadap Keputusan Pembelian Pada Konsumen Kafe Mom Milk Semarang. Diponegoro Journal of Social and Politic, 1-7.

23. Sandy, F., Arifin, Z., \& Yaningwati, F. (2015). Pengaruh Bauran Promosi Terhadap Keputusan Pembelian (Survei pada Mahasiswa Jurusan Bisnis Angkatan 2010-2012 Fakultas IImu Administrasi Pengguna Indosat di Universitas Brawijaya). Jurnal Administrasi Bisnis (JAB), Vol. 9 (2).

24. Sriyanto, A., \& Utami, DA (2016). Pengaruh Kualitas Produk, Citra Merek, and Kualitas Layanan Terhadap Keputusan Pembelian Produk Dadone di Jakarta. Jurnal Ekonomika and Manajemen, Vol. 5 (2)(ISSN: 2252-6226).

25. Togas, NMN, Sepang, JL, \& Wenas, RS (2015). Periklanan, Penjualan Pribadi, Promosi Penjualan and Publisitas Terhadap Keputusan Pembelian Pada Penerbit Andi Cabang Manado. Jurnal EMBA, Vol. 2 (4), 578-588.

26. Utama, LH (2020). Peran Daya Tarik Iklan, Kualitas Produk and Harga Dalam Memengaruhi Keputusan Pembelian Pembersih Wajah. Jurnal IImu Manajemen (JIM), Vol. 7 (1).

27. Utomo, PB, \& Waluyo, HD (2018). Pengaruh Brand Image, Promosi and Kualitas Pelayanan Terhadap Keputusan Penggunaan Jasa (Studi Kasus (Penumpang KA Kaligung PT KAI DAOP IV Semarang). Diponegoro Journal of Social and Politic, 1-5.

28. Vatjanasaregagu, L., \& Thammathira, S. (2017). The Impact Of Service Quality And Consumer Decision Factors On Brand Equity. International Business \& Economics Research Journal, Vol. 6 (3).

29. Wulandari, PP, \& Widayanto. (2020). Pengaruh Promosi and Kualitas Pelayanan Terhadap Keputusan Pembelian Mobil Merek Toyota (Studi Pada Konsumen PT. Nasmoco Majapahit Semarang). Jurnal Universitas Diponegoro. 